
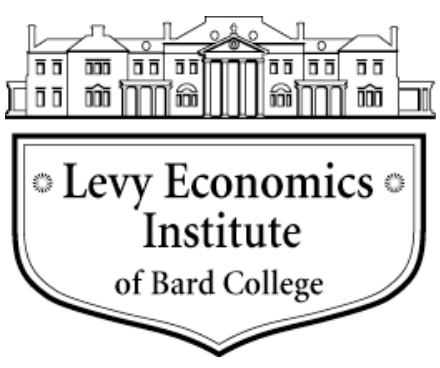

Working Paper No. 852

\title{
The Malady of Low Global Interest Rates
}

by

\author{
Tanweer Akram* \\ Voya Investment Management
}

October 2015

\begin{abstract}
* The author's institutional affiliation is provided solely for the purpose of identification. Views expressed are solely those of the author, and the standard disclaimer applies. In the interest of full disclosure, the author's employer, Voya Investment Management, invests in a wide range of financial assets, including fixed-income securities that are sensitive to interest rates. The author thanks John Lauder for his editorial support and the members of the Voya Fixed Income Research Workshop for their comments and suggestions. Correspondence: Voya Investment Management, 5780 Powers Ferry Road NW, Suite 300, Atlanta, GA 30327; tel: (770) 6904806; fax: +1 (770) 690-5406; e-mail: tanweer.akram@voya.com.
\end{abstract}

The Levy Economics Institute Working Paper Collection presents research in progress by Levy Institute scholars and conference participants. The purpose of the series is to disseminate ideas to and elicit comments from academics and professionals.

Levy Economics Institute of Bard College, founded in 1986, is a nonprofit, nonpartisan, independently funded research organization devoted to public service. Through scholarship and economic research it generates viable, effective public policy responses to important economic problems that profoundly affect the quality of life in the United States and abroad.

\author{
Levy Economics Institute \\ P.O. Box 5000 \\ Annandale-on-Hudson, NY 12504-5000 \\ http://www.levyinstitute.org
}

Copyright (C) Levy Economics Institute 2015 All rights reserved 


\begin{abstract}
Long-term interest rates in advanced economies have been low since the global financial crisis. However, in the United States the Federal Reserve could begin to hike its policy rate, the federal funds target rate, before the end of the year. In the United Kingdom, the Bank of England could follow suit. What is the outlook for global long-term interest rates? What are the risks around interest rates? What can policymakers do to cure the malady of low interest rates? It is argued that global interest rates are likely to stay low in the remainder of this year and the first half of next year due to a combination of domestic and international factors, even if a few central banks gradually begin to tighten monetary policy. The cure for this malady lies in proactive fiscal policy and measures to support job growth. Boosting effective demand and promoting higher wages and real disposable income would help lift inflation rates close to their targets and raise long-term interest rates.
\end{abstract}

Keywords: Government Bond Yields; Global Interest Rates; Long-Term Interest Rates

JEL Classifications: E43, E50, E60 


\section{THE MALADY OF LOW GLOBAL INTEREST RATES}

Since the global financial crisis long-term interest rates on government bonds have been low in major advanced countries. In the United States, however, the Federal Open Market Committee (FOMC), the Federal Reserve's interest rate setting body, could begin to hike the fed funds target rate before the end of this year. The Bank of England may also begin to raise interest rates early next year if the UK economy improves.

There is little reason to believe that low interest rates and quantitative easing have been supportive of growth. Central banks' large-scale asset purchase programs and various emergency measures may have been necessary to ensure that payment and financial systems stayed intact. These programs have supported financial asset prices and have spurred higher net worth of households, particularly high income households. Higher asset prices were expected to induce stronger consumer spending from the wealth effect; in reality they have done little to promote economic growth, real fixed investment, jobs, or wage increases. Even in countries such as the US and Japan, where unemployment rates have declined, it is unclear whether protracted low interest rates have been helpful.

What is the outlook for global long-term interest rates? Will interest rates remain low in the coming six months? What are the risks around interest rates? What can policymakers do to cure the malady of low interest rates? This article will address these questions.

It will be argued that despite the Fed's forthcoming tightening of monetary policy, long-term interest rates in advanced countries are likely to stay low for the remainder of 2015 and the first half of 2016. Policy rates in the advanced economies will stay low, which will keep short-term interest rates low. Inflationary pressures are likely to be muted due to low energy and commodity prices and feeble nominal wage growth. The balance sheets of the major central banks will stay bloated; some will continue large-scale asset purchases while others will try to maintain the size of their balance sheets by reinvesting principal payments for a period even after their first rate hike. Growth in global industrial production and international trade has been disappointing in recent months, particularly in key emerging markets. Global economic activity is likely to remain soft in coming months as effective demand in most economies is tame, while the demand 
for safe assets will be strong. The combination of these factors with the recent turbulence in global financial markets will keep long-term interest rates in the major advanced countries low.

The cure to the malady of low long-term interest rates lies in proactive fiscal policy and enterprising measures to support job growth. Active fiscal policies and public efforts to promote job growth could boost effective demand and lift wage growth and real disposable income. These in turn could raise inflation and long-term interest rates.

\section{LOW LONG-TERM INTEREST RATES: HERE, THERE AND ALMOST EVERYWHERE}

Long-term interest rates are low in almost every major advanced country (figure 1). In the US, long-term interest rates began to decline with the onset of the global financial crisis as the FOMC cut the fed funds target rate, its main policy rate. The Fed fund rate has remained unchanged since late 2008. Meanwhile, long-term interest rates in the US remain at low levels compared to their history (Akram 2015a).

\section{Figure 1. Long-Term Interest Rates among the Developed Economies Stand at 15-Year} Lows

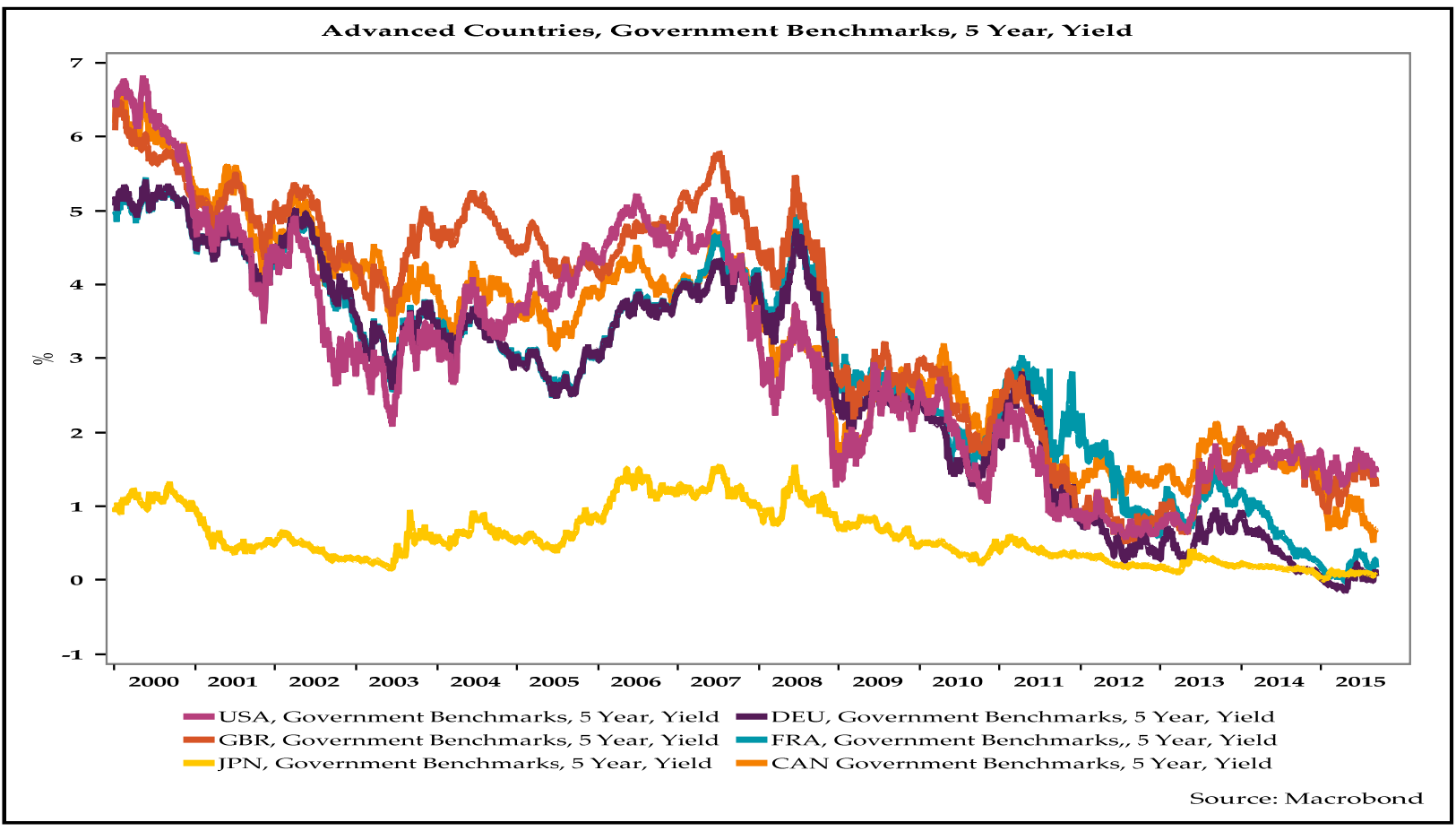


Similarly, long-term interest rates in the UK fell notably in 2008 as the Bank of England (BoE) cuts its base rate several times. The BoE has kept its base rate unchanged since early 2009. As a result, long-term interest rates have remained consistently low.

In Japan long-term interest rates were already quite low before the crisis as the economy had been stagnant for decades (Akram 2014). Still, interest rates fell further following the crisis, as the Bank of Japan (BoJ) reduced its overnight call rate in late 2008. Since then the BoJ kept its policy rate unchanged. Long-term interest rates in Japan have remained very low despite the country's elevated government debt ratio (Akram and Das 2014a, 2014b). Long-term interest rates generally have declined further since the advent of the "Abenomics" and the BoJ's quantitative and qualitative monetary easing.

In the euro zone, long-term interest rates fell as the European Central Bank (ECB) began to cut its refinancing rate in late 2008. Interest rates rose in 2011 when the ECB raised the refinancing rate. In euro zone peripheral countries such as Portugal, Italy, Ireland, Greece, and Spain, longterm interest rates spiked and remained high until late 2012. Investors were concerned about high government-debt-to-GDP ratios, large fiscal deficits, default, and political risks, including the possibility of exit from the euro zone (Akram 2015b). These concerns did not fade until the ECB made clear that it was committed to providing liquidity to the financial system, keeping yields contained on euro zone government bonds, taking appropriate measures to ensure the stability of the financial system, and keeping the common currency. Since mid-2013 interest rates have declined markedly for most euro zone countries, including Italy and Spain; by contrast, not for Greece as investors remain concerned about the country's debt sustainability and possible exit from the euro zone. Meanwhile, the ECB has reduced its deposit rate below zero. This has resulted in low or even negative nominal bond yields in a number of euro zone countries, including Belgium, Germany, Finland, France, Austria, and the Netherlands, as well as other European countries outside the euro zone, such as Switzerland and Norway (figure 2). 
Figure 2. Negative and Exceptionally Low Bond Yields Prevail in Several Key European Economies

\begin{tabular}{|l|c|c|c|c|c|c|c|c|c|c|c|}
\hline \multicolumn{7}{|c|}{ Yields on European sovereign bonds (Aug 20, 2015) } \\
\hline Tenor (years) & 0 & 1 & 2 & 3 & 4 & 5 & 6 & 7 & 8 & 9 & 10 \\
\hline CHE & & & & & & & & & & & \\
\hline DNK & & & & & & & & & & & \\
\hline DEU & & & & & & & & & & & \\
\hline SWE & & & & & & & & & & & \\
\hline FIN & & & & & & & & & & \\
\hline AUT & & & & & & & & & & \\
\hline NLD & & & & & & & & & & & \\
\hline FRA & & & & & & & & & & & \\
\hline BEL & & & & & & & & & & & \\
\hline ESP & & & & & & & & & & & \\
\hline ITA & & & & & & & & & & & \\
\hline NOR & & & & & & & & & & & \\
\hline
\end{tabular}

Long-term interest rates in Canada also remained low, largely in lockstep with the US, as the Bank of Canada (BoC) cut its overnight rate during 2007-09. The BoC's policy rate hike in 2010 did not affect the long-term interest rates: Canadian long-term interest rates, particularly at the back of the yield curve of government securities, continued to largely follow US Treasury yields. Since the beginning of 2014, however, long-term interest rates in Canada have been lower than the US. The spread widened further as the BoC began lowering its overnight rate in 2015 due to the emerging weakness of the Canadian economy.

Recent trends in Fed fund futures and other interest rate markets suggest that investors are pricing in Fed hikes but are uncertain about the timing of the first hike, the pace of tightening, and the "terminal" fed funds rate. Investors are jittery and appear to be weighting unfavorable news more than favorable news. Likewise in the UK, investors expect the BoE to begin easing as reflected by the implied bank rate conditioning path. In recent years, however, expectations of BoE rate hikes have often stayed unrealized as the UK economy has proven weaker than investors believed. 


\section{DRIVERS OF LONG-TERM INTEREST RATES}

According to standard theory, interest rates generally should be positive because of positive time preference as argued in Fisher (1930) and Olson and Bailey (1981), as cited in Edwards (1991). von Mises (1963), also cited in Edwards (1991), noted that "satisfaction of a want in the nearer

future is, other things being equal, preferred to that in the further distant future. Present goods are more valuable than future goods." Indeed, for most of bond market history, nominal yields on government bonds have been positive.

Keynes did not accept the classical view of interest rates. He held that the ultimate basis of interest rates lies in human psychology, social convention, and liquidity preference. Though he did not conceive or foresee that nominal interest rates would be negative, Keynes's (1930, 2007 [1936]) astute observation still holds that the central bank sets risk-free, short-term interest rates on Treasury bills, which in turn influence the yield curve on government bonds. Keynes argued that the investor takes his cue about long-term interest rates from current conditions and the nearterm outlook. As a result, short-term interest rates and changes in short-term interest rates are respectively the crucial determinants of long-term interest rates and the changes in long-term rates. The post-crisis experience of persistently low long-term interest rates in the major advanced economies with monetary sovereignty, despite tremendous increases in the balance sheets of key central banks, accords with Keynes's conjectures about the determinants of longterm interest rates.

Since World War II, the main drivers of long-term interest rates in advanced economies have been short-term interest rates, inflation, inflation expectations, and economic activity. The level of economic activity influences inflation and inflation expectations. The central bank's policy rates, which influence short-term interest rates, are set in response to observed inflation, expected inflation, and effective demand. Generally, short-term interest rates move in tandem with the central bank's policy rates (figure 3). Short-term rates and long-term rates usually move hand in hand. Scatterplots show that these rates are strongly correlated (figure 4). What's more, percentage point changes in long- and short-term interest rates are also positively correlated, though less so than the strong correlation between the levels of long-term and short-term interest rates (figure 5). The nominal yields of government bonds also tend to move in tandem with core inflation (figure 6). 
Figure 3. Short-Term Interest Rates Move in Tandem with Fed Funds Target Rate

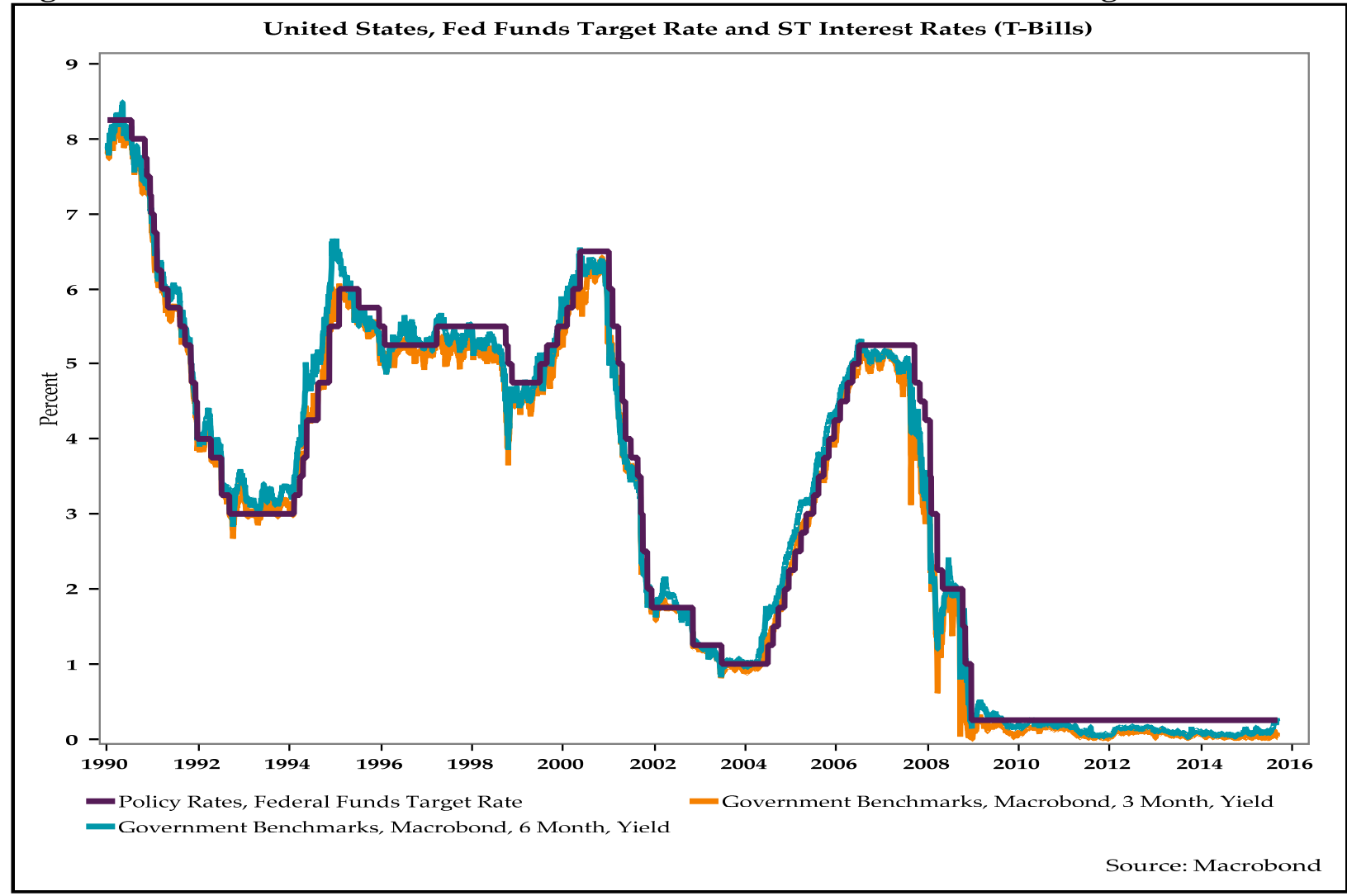

Figure 4. Long-Term Interest Rates and Short-Term Interest Rates Are Strongly Correlated

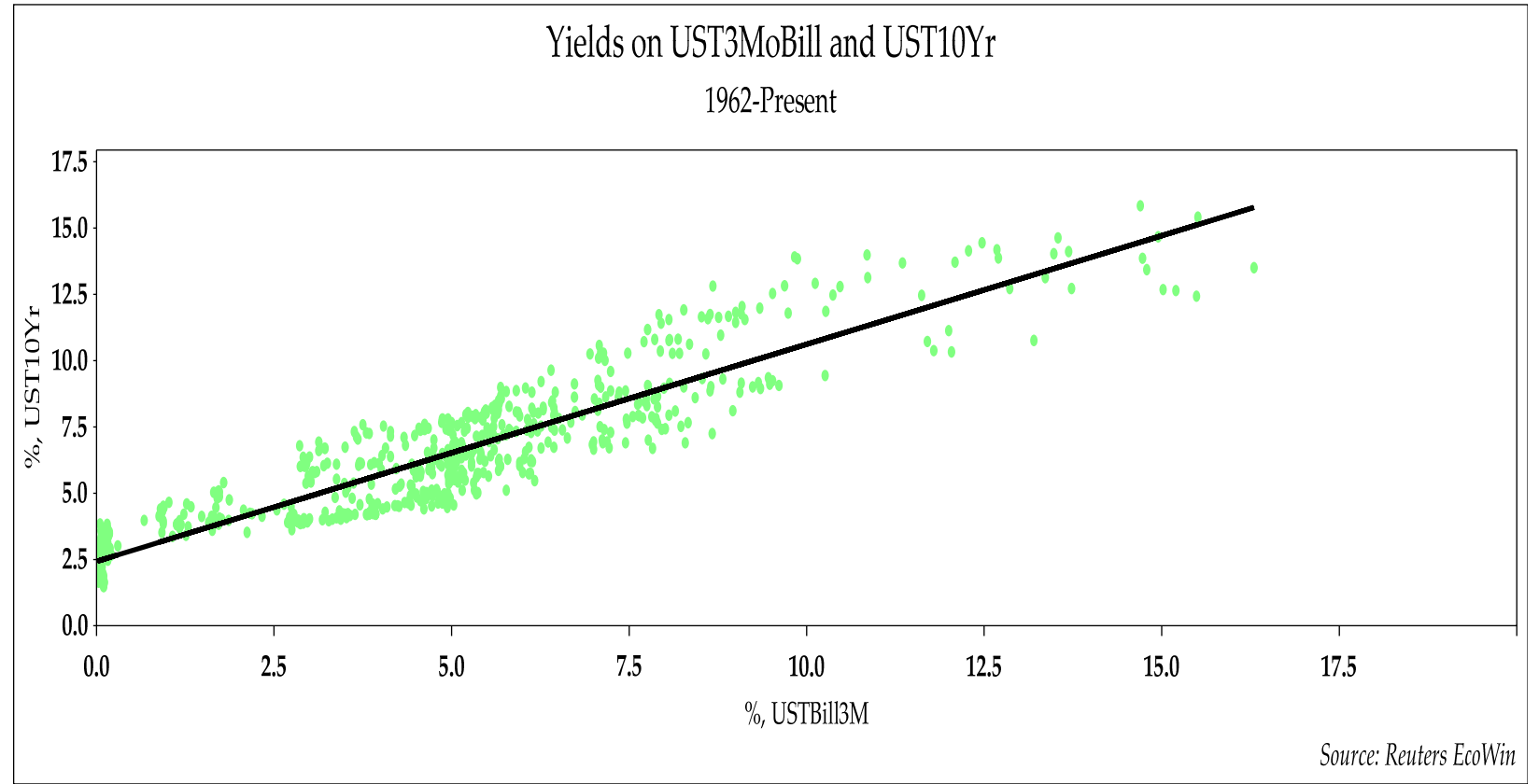


Figure 5. Year-over-Year Percentage Point Changes in Long- and Short-Term Interest Rates Are Positively Correlated

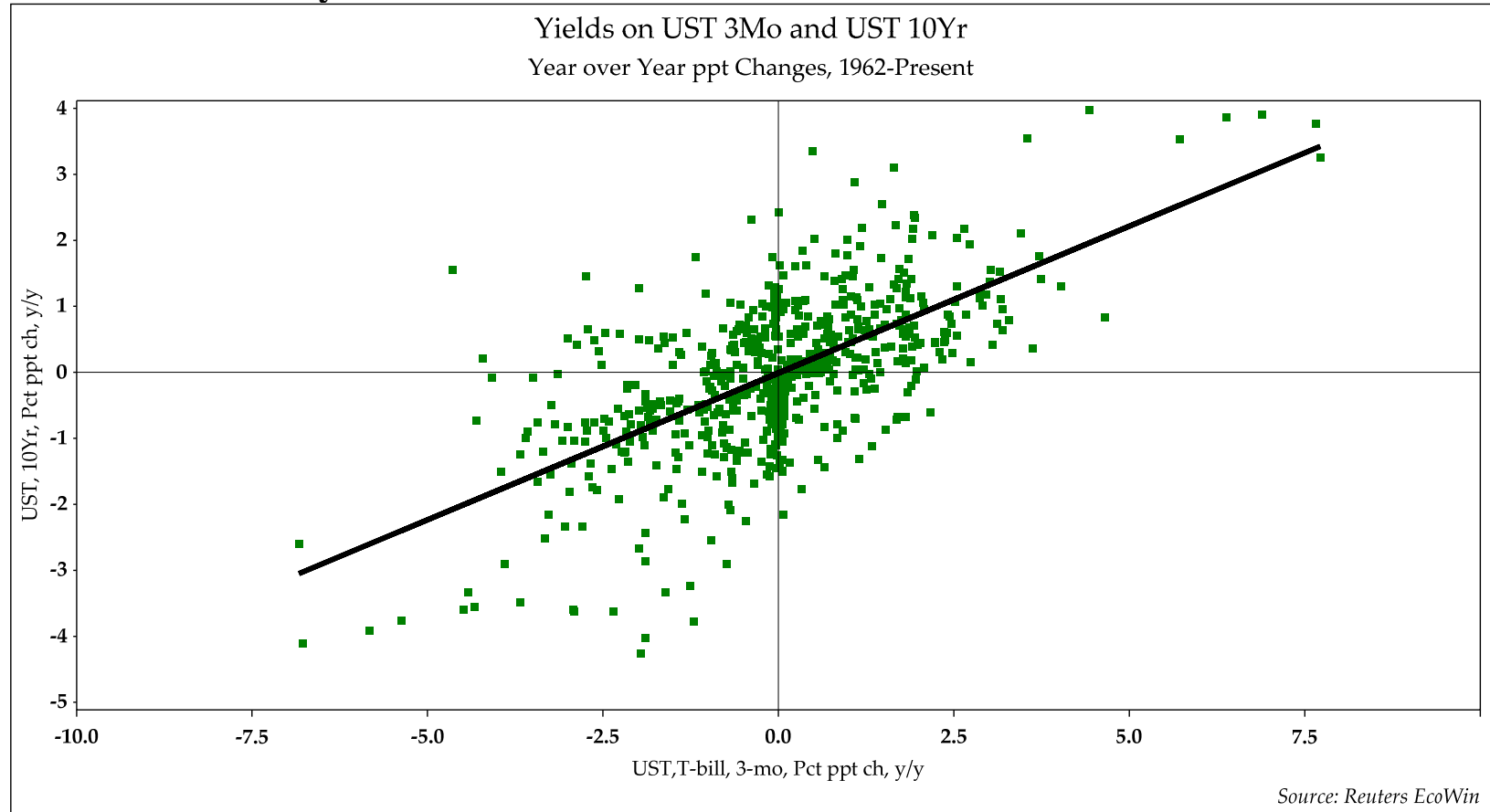

Figure 6. The Core Inflation Rate Is a Key Driver of US Treasury Yields

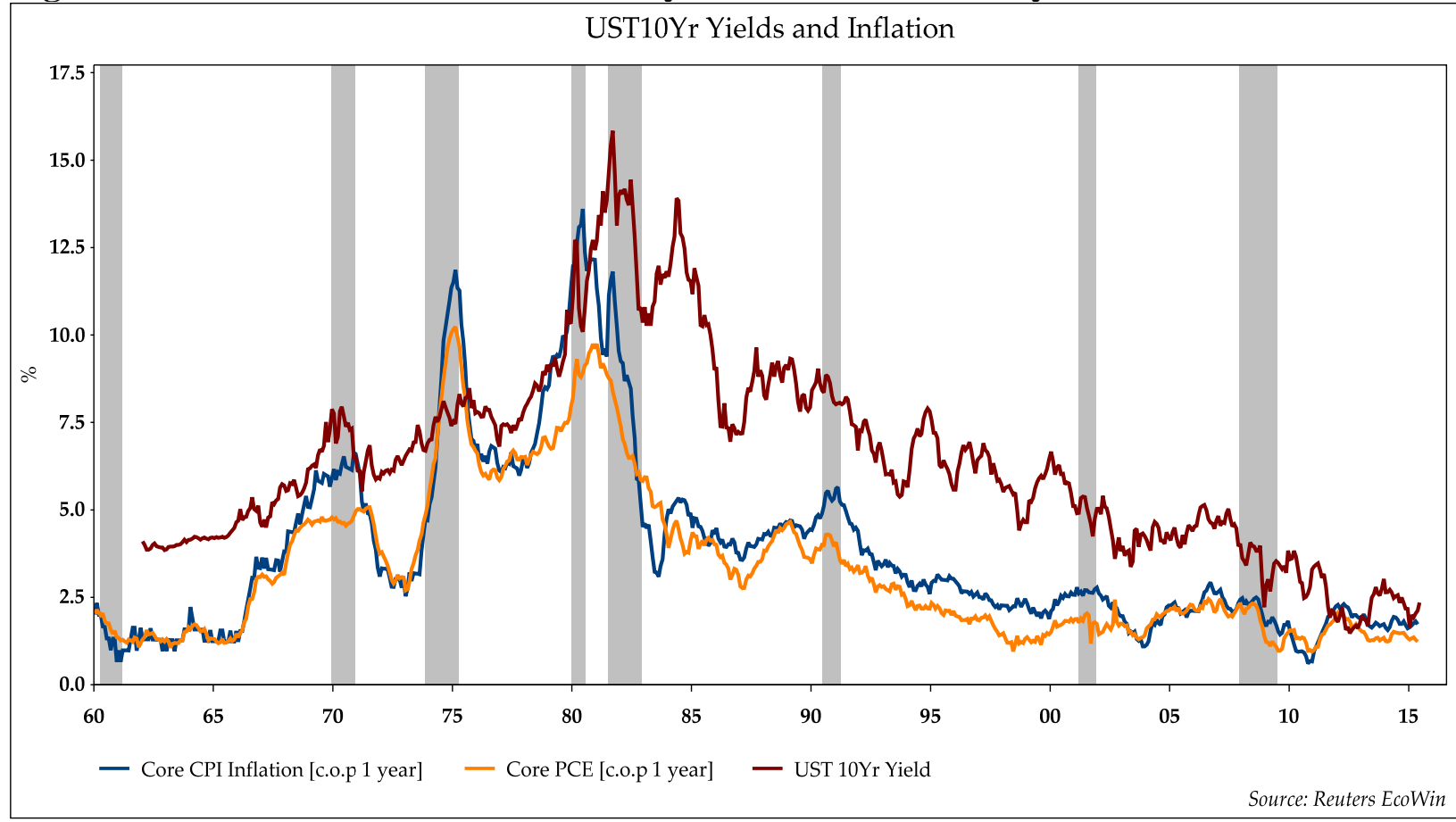


Policy rates in most advanced countries have been exceptionally low since 2008 (figure 7). As a result, short-term interest rates in these countries also have stayed low (figure 8). Since the global financial crisis a few central banks have raised policy rates but have had to reverse their hikes. The BoC raised its overnight rate from 25 basis points (bps) thrice in 2010 by 25 bps each time. It kept policy rates unchanged until it began cutting its policy rate in 2015, first in January and again in July. The ECB raised its policy rate twice in early 2011 but was forced to reverse course later that year. It was again forced to cut in 2012 and 2013, followed by further reductions to very low levels in 2014. A number of other central banks that tightened policy after the financial crisis, such as Sweden's Riksbank, the Reserve Bank of Australia, and the Reserve Bank of New Zealand, also have had to reverse course.

\section{Figure 7. Major Central Banks' Policy Rates Have Been Exceptionally Low Since 2008}

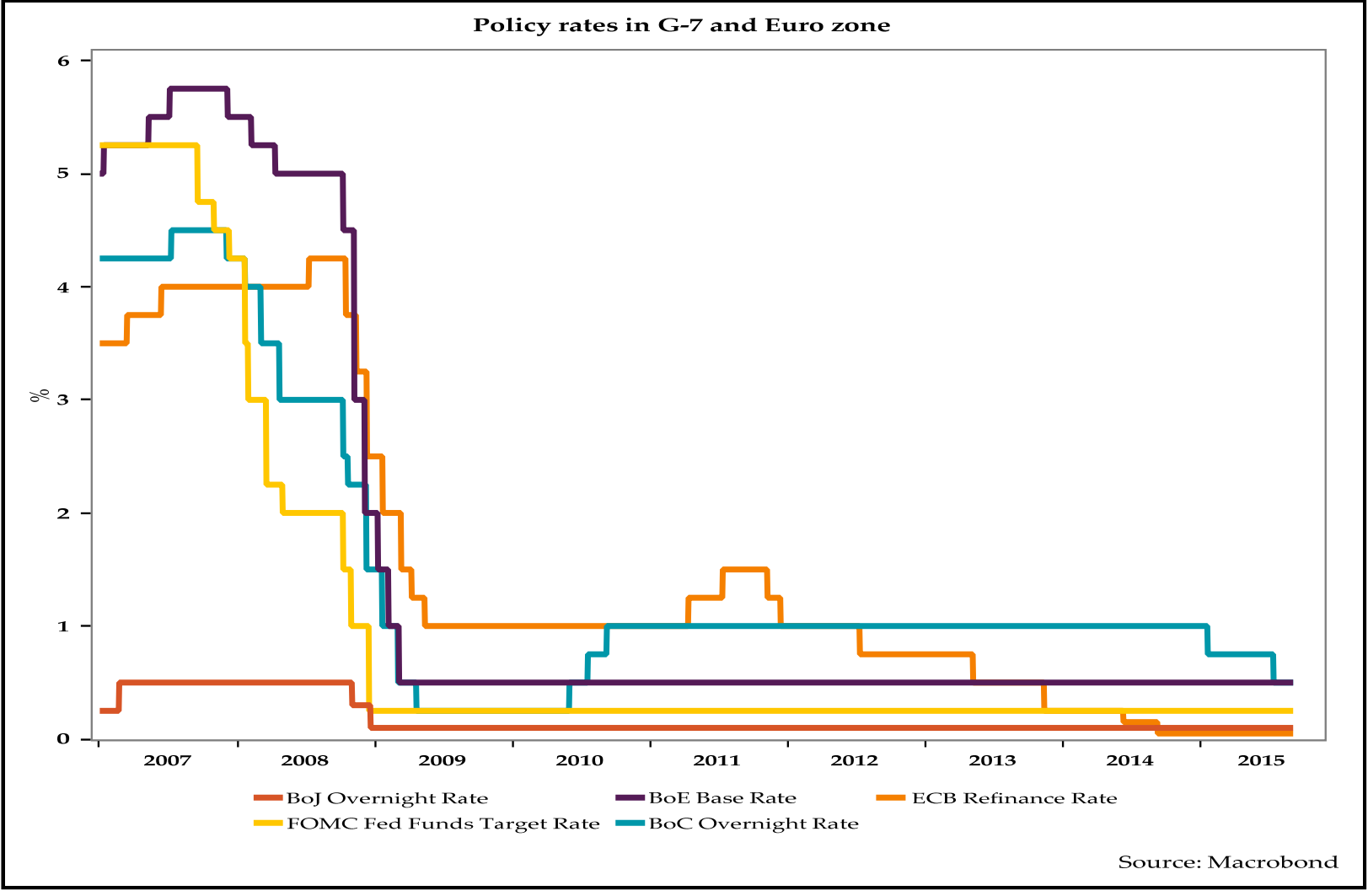




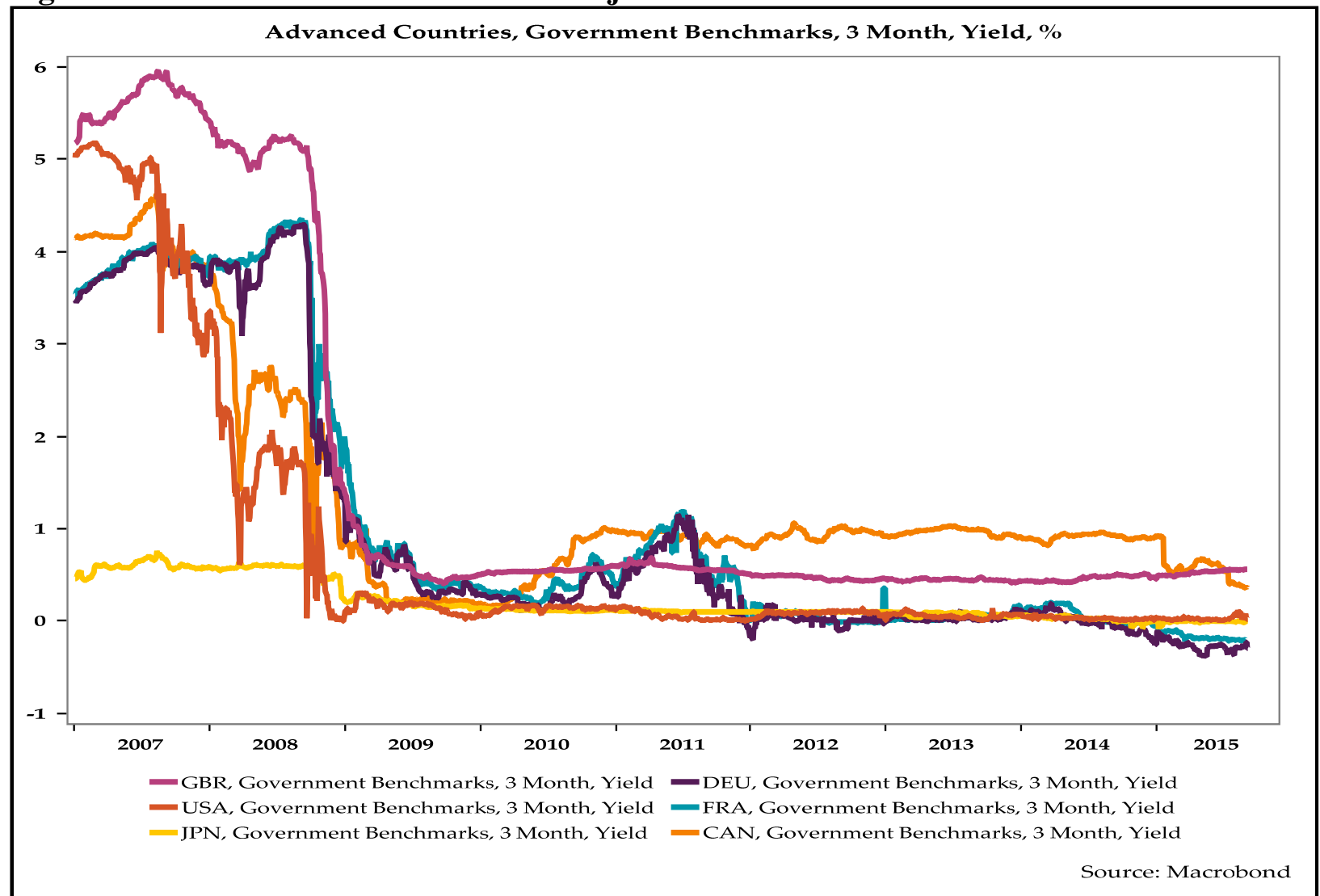

\section{NEGATIVE BOND YIELDS IN EUROPE}

Until recently it was widely held that zero would set the lower bound for interest rates. As the Swiss National Bank, Sweden's Riksbank, and the ECB introduced negative deposit rates, however, yields to maturity on money market instruments including Treasury bills turned negative; yields on government bonds of longer tenors for several euro zone and other European countries later followed suit.

Since household and firms can hold cash (notes) instead of government securities it would seem that they would not accept negative rates. But there are costs to holding cash including storage costs, inconvenience, and insurance. Custom, caution, and behavioral conservatism may make households, banks, and financial institutions willing to accept negative rates. What's more, if investors expect deflation, then even if nominal yields are negative expected real yields could be positive. For example, if the nominal yield on a government bond of one year is $-1 \%$, but 
investors expect deflation at a rate of $2 \%$ for the year ahead, then the expected real yield from holding a one-year bond would be $-1 \%-(-2 \%)=+1 \%$. Even if the expected real yield is not positive, investors might be willing to accept negative nominal yields in an economic environment of heightened uncertainty, debt deflation, deflationary expectations, and increased volatility.

\section{LOW INFLATION AND SUBDUED INFLATIONARY EXPECTATIONS}

Current inflationary pressures, as reflected in actual inflation and various metrics of inflationary expectations, are subdued and contained. Global import prices have been declining (figure 9). Energy prices are low and have been declining. Core inflation rates are weak in almost all major advanced countries. Core inflation rates are notably below $2 \%$ in many advanced economies (figure 10). In the United States, nominal wage growth is still subdued. Low employment cost index (ECI) and low unit labor costs (ULC) keeps core inflation in check (figure 11). The containment of labor costs has been keeping inflationary pressures in check in advanced economies. It is true that the US labor market has tightened, as reflected in the decline of the official unemployment rate and broader measures, such the U-6 unemployment rate. Yet wage growth has been moderate because of the weakness in workers' bargaining power, deunionization, the growth of the service sector, globalization of production, outsourcing, changes in the workplace, and a sociopolitical climate that is adverse to workers.

Inflation expectations are quite tame. If anything, market-based inflation expectations appear to be unanchored on the downside (figure 12). Other indicators of inflation expectations, such as surveys of professional forecasters and surveys of consumers, also reinforce the impression of weakness. 
Figure 9. Global Import Prices Have Been Falling Sharply

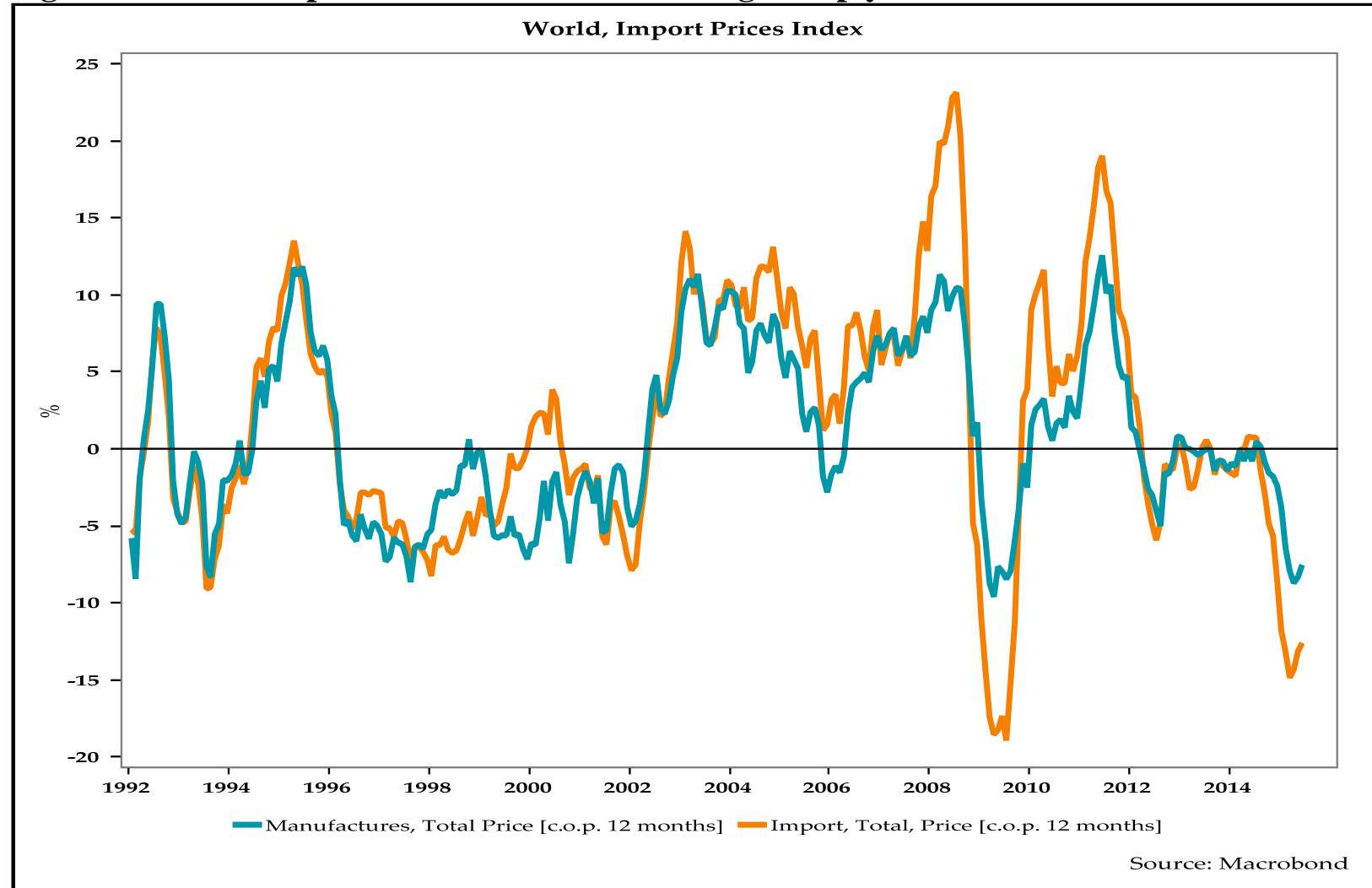

Figure 10. Core Inflation Rates Are Below 2\% in Many Advanced Economies

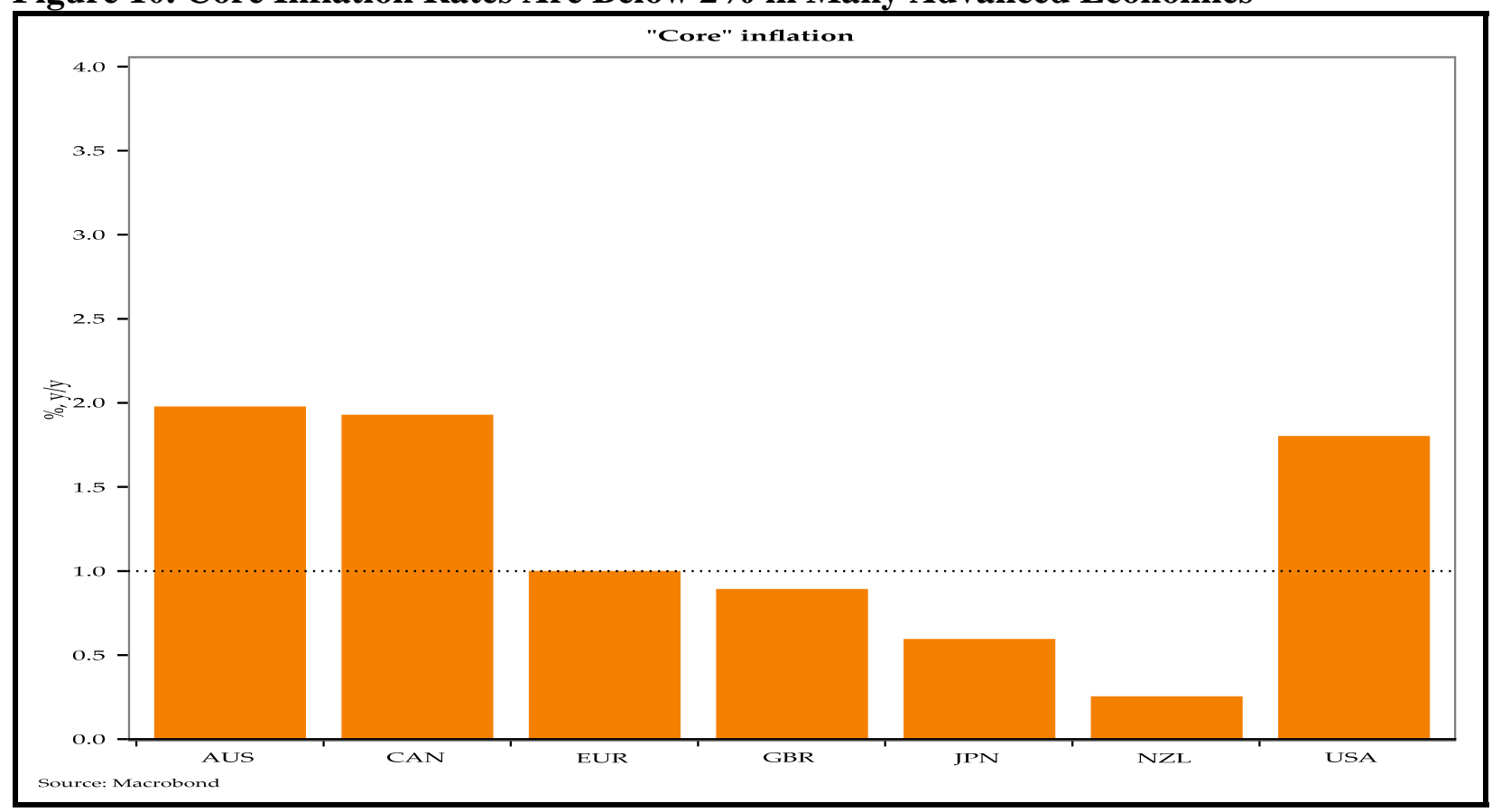


Figure 11. Low Employment Costs Have Kept Core Inflation in Check in the US

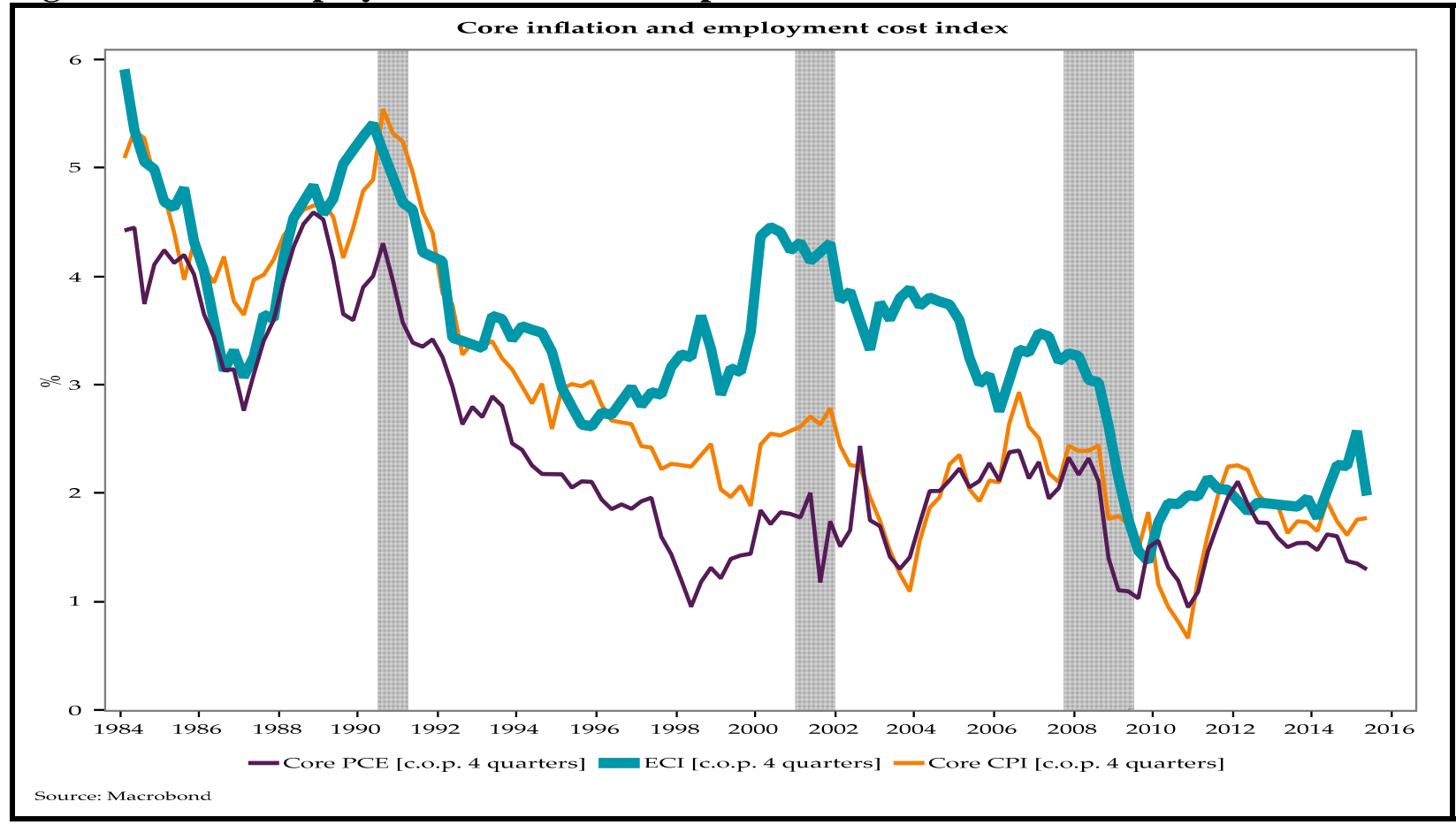

Figure 12. Inflation Expectations Are Tame and Appear to Have Become Unanchored on the Downside






\section{CENTRAL BANKS’ BLOATED BALANCE SHEETS}

The balance sheets of the major central banks of the advanced countries are bloated thanks to large-scale asset purchases and various other measures that these central banks have taken to provide liquidity and support financial institutions. The elevated size of central banks' balance sheets supports low long-term interest rates and acts to offset upward pressures on interest rates.

The Fed's balance sheet rose sharply in mid-2008 as a result of the emergency measures that the Fed undertook in response to the crisis (figure 13). It expanded notably in late 2010 to mid-2011 as the Fed began to purchase long-term US Treasury securities. From late 2012 to mid-2014 the Fed's balance sheet rose sharply once again as policymakers ramped up purchases of Treasury securities and agency mortgage-backed securities. Since the tapering and the ending of the latest quantitative easing program the Fed's balance sheet has stabilized.

\section{Figure 13. The Evolution of the Fed's Balance Sheet}

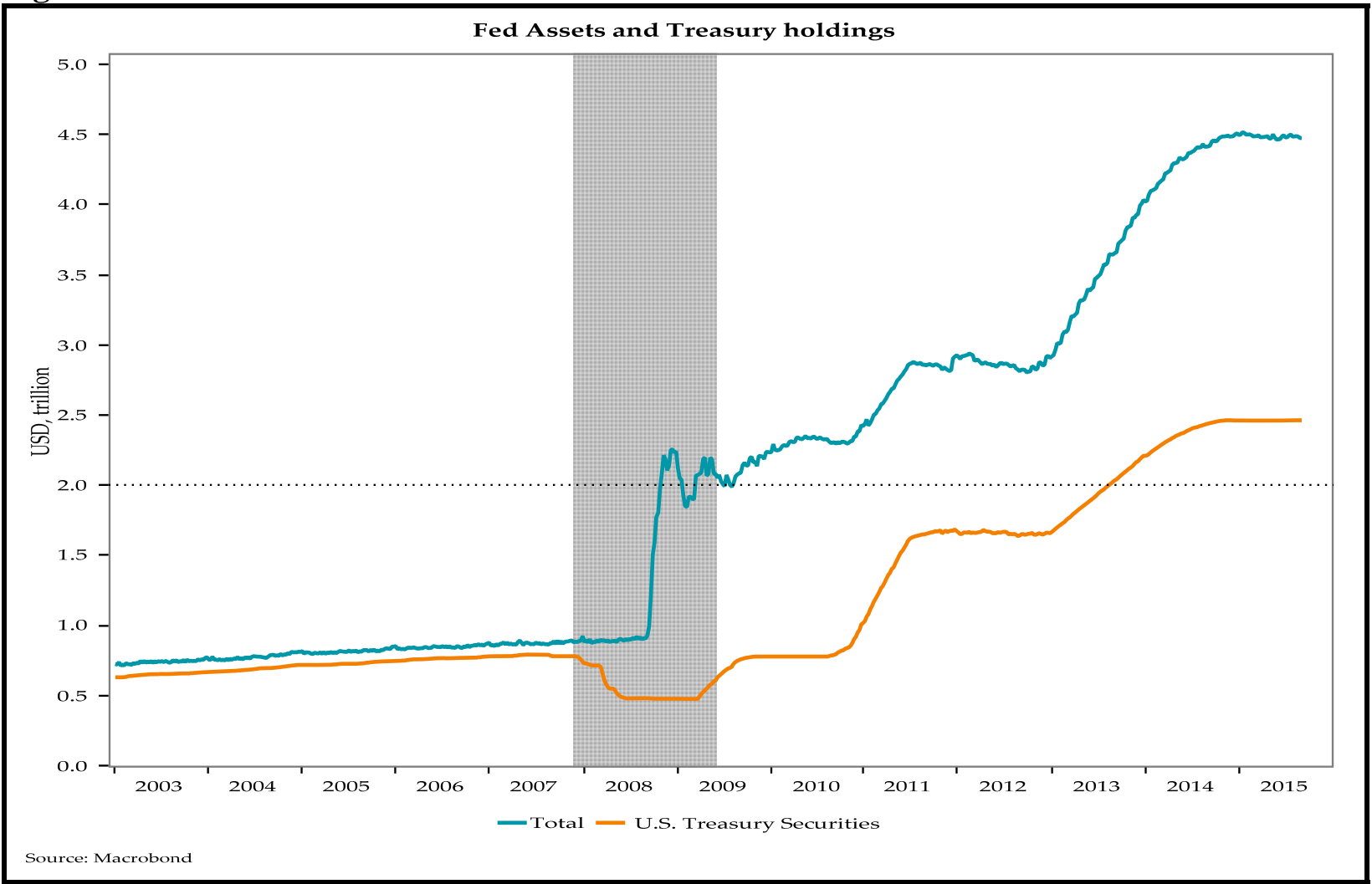


The ECB's balance sheet (figure 14) rose in early 2009 and increased sharply in 2011 as banks and financial institutions needed liquidity during the euro zone debt crisis. After declining somewhat in 2013, the ECB's balance sheet began to rise again in 2014.

\section{Figure 14. The Evolution of the ECB's Balance Sheet}

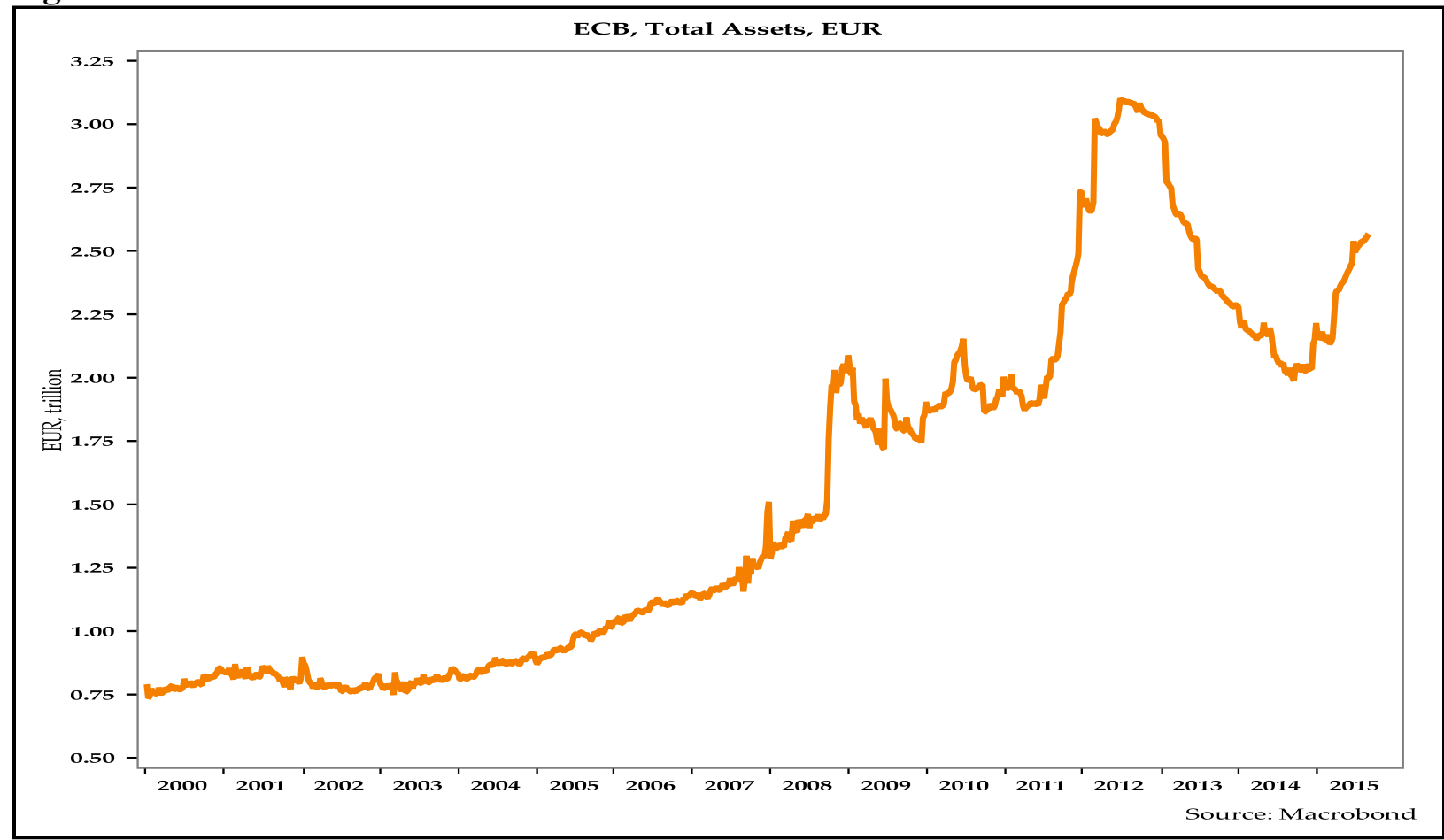

The BoJ's balance sheet (figure 15) expanded at a steady pace between 2001 to late 2005, but declined as the central bank came off its zero interest rate policy in 2006. Its balance sheet rose moderately after the financial crisis. It was only in 2012 after the advent of "Abenomics" that the BoJ's balance sheet began rising noticeably. After the installation of Haruhiko Kuroda as the governor of the BoJ and the advent of quantitative and qualitative monetary easing, the BoJ's balance sheet rose sharply. The BoJ has been an aggressive buyer of Japanese government bonds since 2013. 




The balance sheets of the major central banks are likely to remain elevated as these central banks are either continuing to expand their asset purchases or reinvesting principal payments. Fed policymakers have stated they would wait until well after they begin to hike the fed funds target rate to begin a gradual shrinking of the central bank's balance sheet.

\section{MUTED GLOBAL ACTIVITY}

Growth in economic activity, as measured by industrial production, is muted world-wide (figure 16). Industrial production is a good indicator of cyclical global business conditions even though services constitute the bulk of economic activity, particularly in advanced countries. Industrial production is more cyclically sensitive than activity in services and tends to lead the fluctuation of overall economic activity. Growth in global industrial production today is slowing compared to a year ago. For advanced countries year-over-year industrial production growth is negligible, 
while for the emerging market it is softening. Since the beginning of 2008, levels of industrial production have not risen much in advanced countries. US industrial production is slightly above its 2008 level, whereas for Germany it is slightly below. For Japan it is significantly lower. Industrial production is notably weak in Latin America, central and eastern Europe, and the euro zone. It is still rising year-over-year in Asia excluding Japan but at a slower pace than in the recent past.

Figure 16. Global Industrial Production Is Soft, with Negligible Growth in Advanced Economies and Slowing in Emerging Markets

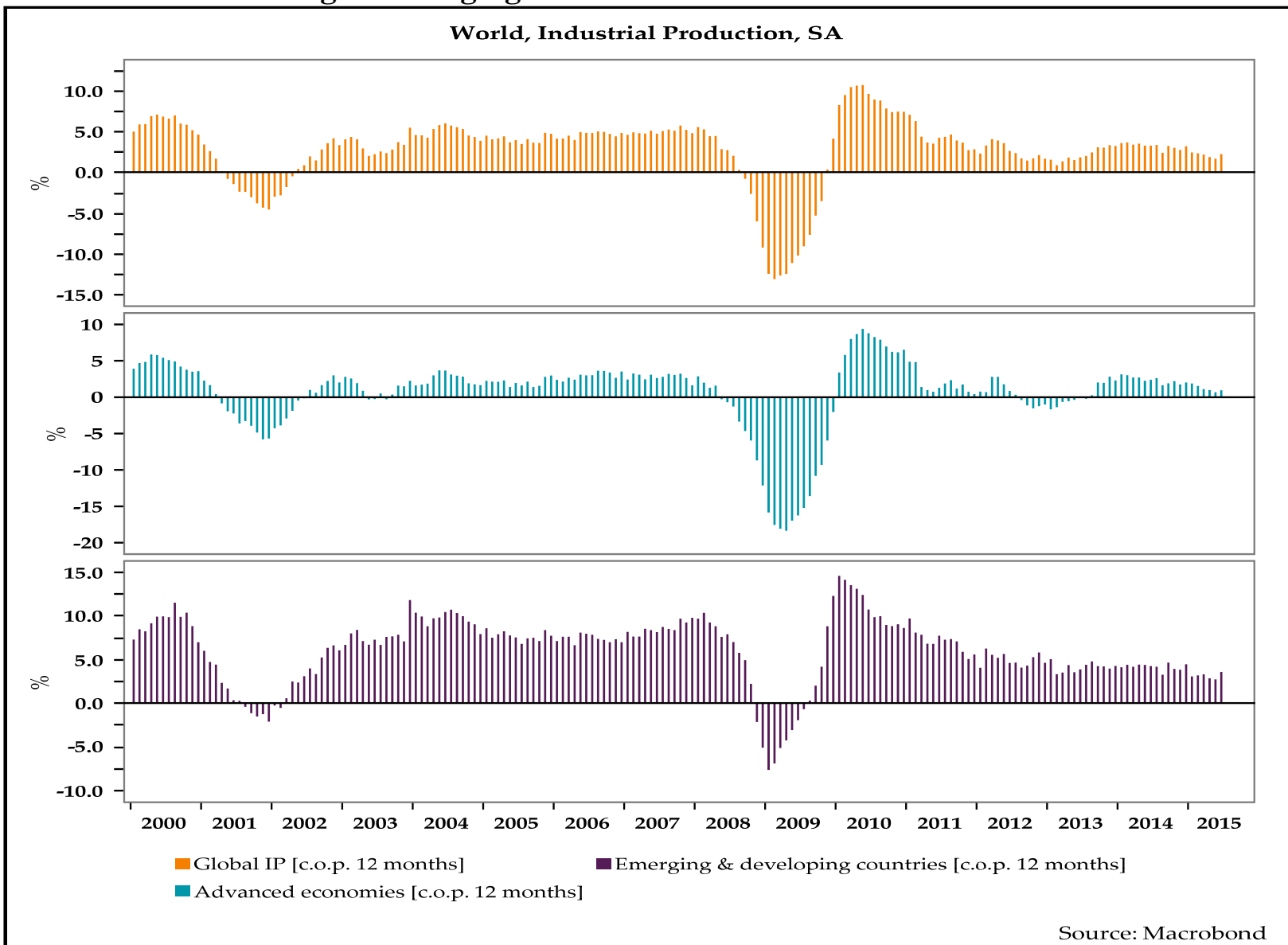

Key emerging markets are experiencing slowdown. Industrial production is tumbling in Brazil and Russia; it has markedly slowed in China while continuing to grow in India (figure 17), though India's contribution to global industrial production is still quite small. Global trade has slowed, reflecting the slowdown of industrial production. The volumes of Asian exports and 
imports have been weakening since the beginning of the year. Intra-Asian trade is a substantial and useful measure of global production and trade. A strong dollar and muted economic growth in the rest of the world has hurt US exports, but US imports are rising, having benefited from dollar strength and the moderate pace of US growth.

\section{Figure 17. BRICs Industrial Production Disappoints with the Exception of India}

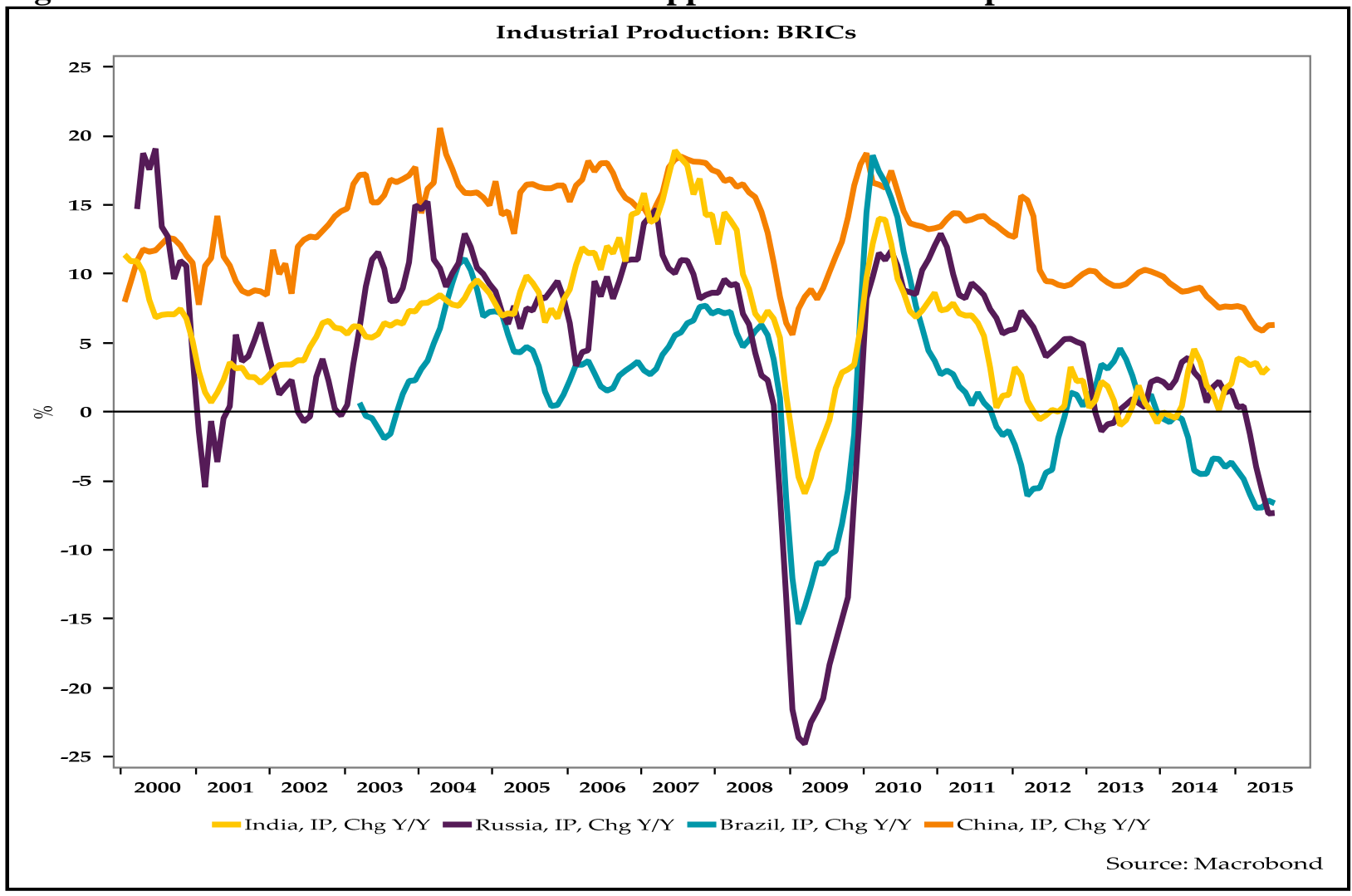

\section{THE RESILIENT DEMAND FOR SAFE ASSETS}

The demand for safe assets, such as government bonds, is strong. Investors continue to pour money into government bonds of major advanced countries, particularly US Treasury securities. Foreigners hold more than $\$ 6$ trillion in US Treasury securities (figure 18). Despite recent slight declines in official Chinese and Japanese holdings of US Treasury securities, demand is expected to remain strong. Since the global financial crisis, foreign net purchase of US securities has been strong. Purchases have softened somewhat in the last two years, but foreign holdings of Treasury securities remain robust. The experiences of the global financial crisis and the euro zone's 
problems have reinforced demand for securities perceived as safe. Investor appetite is robust for government bonds of countries with sovereign currencies, such as the US, UK, Japan, Canada, and Switzerland. Within the euro zone, where countries do not have monetary sovereignty, demand for German Bunds has risen sharply due to the flight to safety. Bond yields for most euro zone countries have stayed low since Mario Draghi said the ECB is prepared to do whatever it takes to preserve the euro, followed by ECB programs to provide liquidity and support asset prices. Large-scale purchases of government bonds by central banks have created a shortage of safe assets for private investors, further increasing their prices and keeping long-term interest rates on government bonds low. Jitters in global equity markets and in particular the tumbles this August (figure 19) have contributed to the resilient demand for safe assets. Even if foreign central banks slightly reduced their holdings of US Treasury securities and other assets, the overall demand for US Treasury securities would likely remain quite strong.

\section{Figure 18. Foreign Demand for US Treasury Securities Is Strong}

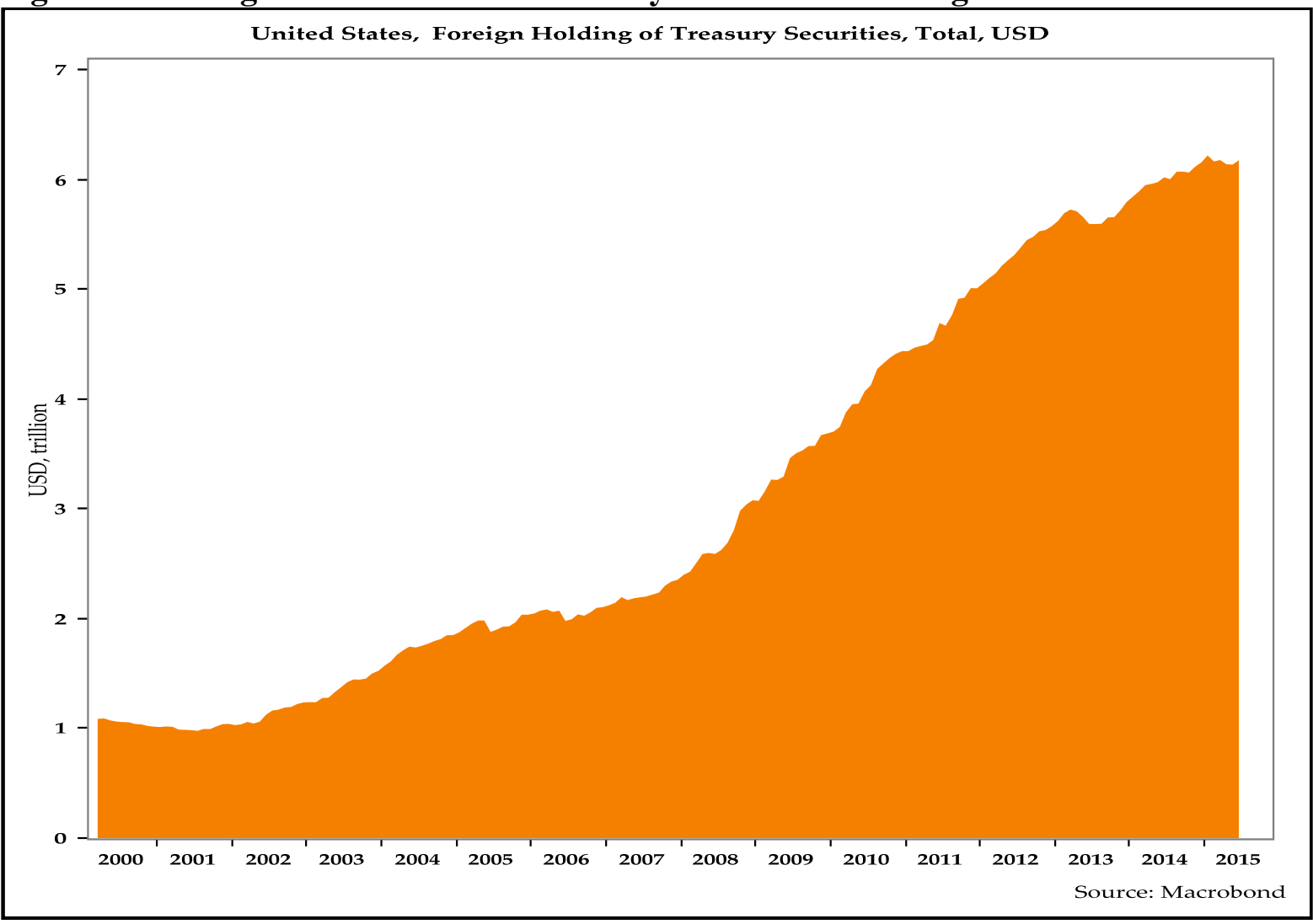




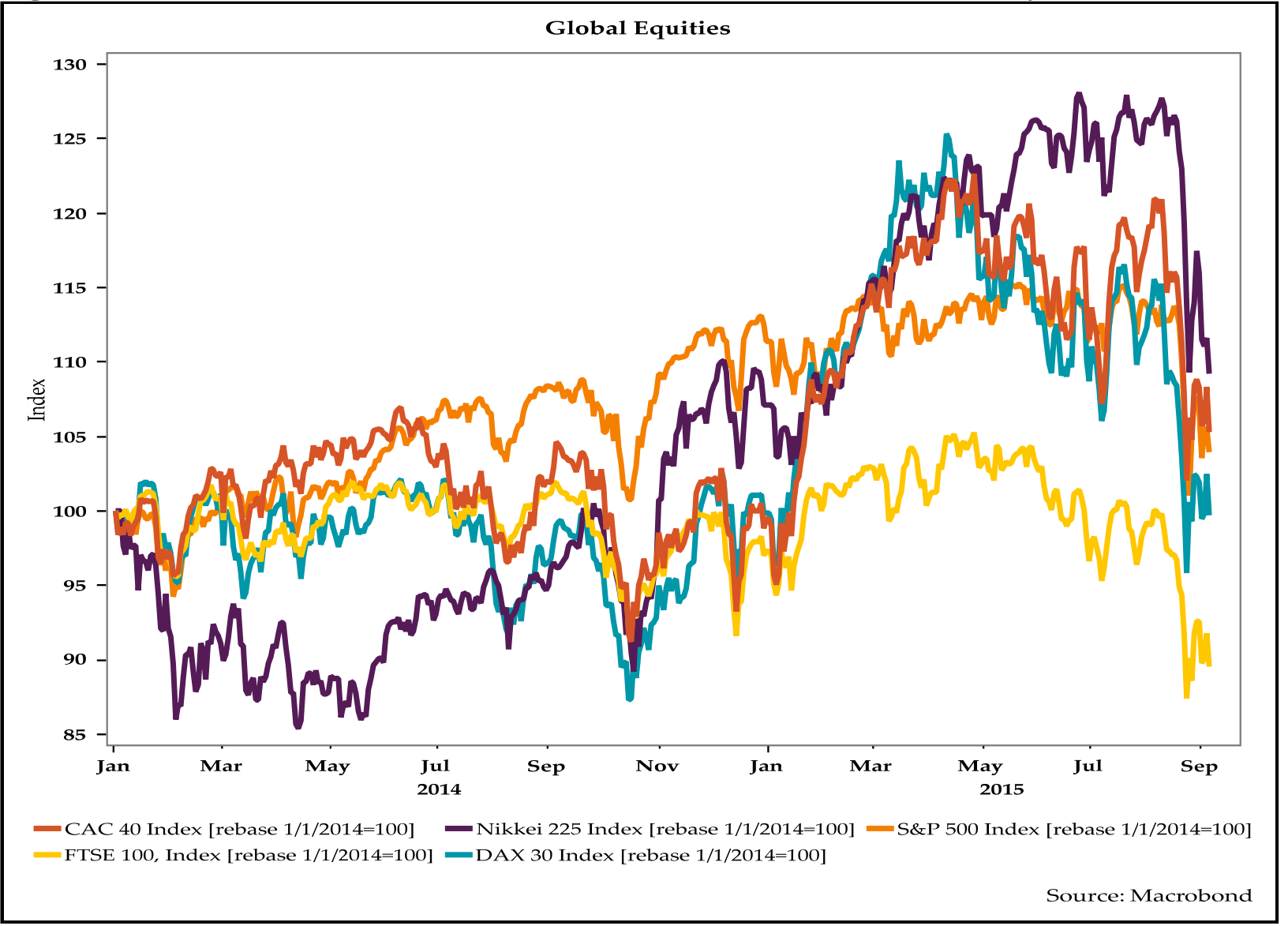

\section{THE BALANCE OF ECONOMIC RISKS}

The balance of risks for the global economy is tilted to the downside. This means that long-term interest rates could stay low longer than currently expected, and perhaps even decline, if the global economy were to unravel. Weakness in the US and further slowdown in China could pose serious problems for the global economy. Another downside risk is that the tepid recovery in the euro zone could quickly erode. On the upside, if wages begin to rise as the US labor market tightens, the Fed might be compelled to become more aggressive in tightening monetary policy in order to curb inflationary pressure. The BoE might follow suit if the UK economy continues to improve. Better economic performance and higher inflationary pressures in the US and the UK could force interest rates higher than anticipated in early 2016. This analyst, however, gives more weight to downside risks than to upside risks for the global economy. 


\section{THE CURE TO THE MALADY OF LOW INTEREST RATES}

Low interest rates in the major advanced economies are really symptoms of the ills that afflict the global economy: low economic growth and core inflation rates below targets. Overcoming low global growth and associated low long-term interest rates will require policies to boost economic activity; accommodative monetary policy has not been enough.

The euro zone and countries such as the UK and Canada have tried fiscal austerity. The euro zone periphery is suffering from years of austerity that proved to be counterproductive (Akram 2015b). In the euro zone, unemployment rates are elevated, while the ratios of periphery countries' debt to GDP have stayed high. Policymakers will need to shun fiscal austerity if they want to overcome the current malaise of low growth.

There are feasible alternatives to austerity. Fiscal policy will have to be reoriented to support job and wage growth, to build twenty-first-century infrastructure, to cope with global warming and environment challenges, and to support healthcare and demographic transitions in advanced countries.

The first priority of advanced countries should be programs to create jobs. Job creation should not be left solely to the private sector, but should involve the public sector and public-private partnerships. Public policy has to take an active role in job creation. There is still considerable unemployment, underemployment, and underutilization of labor in many advanced economies, even though official unemployment rates may seem quite low. The public sector can directly hire workers (Forstater 1998). Public-sector job creation can help stabilize wages and prices (Mitchell 1998). It can also support skill acquisition in the labor force, maintain human capital, serve public good, and accomplish socially useful objectives. It can be a useful instrument for macroeconomic stability. The challenge will to be design and efficiently administer and manage large-scale employment programs and to envision this as a viable countercyclical and pro-growth strategy. Well-designed and properly managed large-scale employment programs could boost effective demand and lift real wages and real disposable incomes.

Prolonged periods of low interest rates can be counterproductive, particularly if fiscal policy is restrictive and public policy fails to generate employment growth and support appropriate public and private investment. Sakuma (2015) points out that as the spreads between short-term interest 
rates and long-term interest rates narrow, commercial banks can become conservative in lending. This hampers businesses' fixed investment in equipment, structures, and intellectual property products and growth in overall economic activity. Low interest rates could lead to a vicious cycle of low inflation and deflation amid weak effective demand. Debt deflation amplifies the weakness of effective demand (Fisher 1933). Overcoming the malaise of low interest rates and deflationary trends will require concerted action on the part of fiscal authorities and the central bank. Samuelson (1945), cited in Kregel (2015), argues that higher interest rates could be beneficial to the banking system and would not necessarily be detrimental to fixed-income investors or to the growth of effective demand. In the midst of spare capacity, a moderate rise in interest rates can provide more interest income and spur household spending. The evidence that low interest rates promote investment and consumer spending is not too compelling. Despite low interest rates, in the current global environment the weakness of effective demand is keeping growth and investment feeble.

\section{CONCLUSION}

Long-term interest rates in major advanced countries will stay low for the remainder of 2015 and in early 2016 because of the combination of domestic and global factors that have kept global interest rates low for many years-even if the Fed begins to hike and the Bank of England follows suit. Domestic conditions, such as central banks' low policy rates, low short-term interest rates, subdued inflation and inflationary expectations, and weak effective demand are the main drivers of low long-term interest rates. Global conditions are reinforcing these drivers. Global inflation is low due to weak energy and commodity prices, declining prices of imported goods, and a strong US dollar. It will take bold, imaginative, and proactive fiscal policy and large-scale employment programs to rekindle economic prosperity and cure the malady of low global interest rates. 


\section{REFERENCES}

Akram, T. 2014. “The Economics of Japan's Stagnation.” Business Economics 49(3): 156-75.

Akram, T. 2015a. "The Persistence of Low Long-Term Interest Rates in the US." Voya Market Insight, May 22. Available at:

https://investments.voya.com/idc/groups/public/documents/market_commentary/131450. pdf

Akram, T. 2015b. “Euro Zone Prospects for Economic Recovery.” Voya Market Insight, August.

Akram, T., and A. Das. 2014a. "Understanding the Low Yields of the Long-Term Japanese Sovereign Debt." Journal of Economic Issues 48(2): 331-40.

Akram, T., and A. Das. 2014b. "The Determinants of Long-Term Japanese Government Bonds' Low Nominal Yields." Levy Economics Institute Working Paper No. 818, October.

Bloomberg. various years. Bloomberg Professional, subscription service (accessed Sep 4, 2015).

EcoWin Reuters. various years. Thomson Reuters EcoWin, subscription service (accessed June 30, 2015).

Edwards, J.R. 1991. Macroeconomics: Equilibrium and Disequlibrium Analysis. New York: Macmillan.

Fisher, I. 1930. The Theory of Interest. New York: The Macmillan Company.

Fisher, I. 1933. "The Debt-Deflation Theory of Great Depressions." Econometrica 1(4): 337-57.

Forstater, M. 1998. "Flexible Full Employment: Structural Implication of Discretionary Public Sector Employment.” Journal of Economic Issues 32(2): 557-64.

Keynes, J.M. 1930. A Treatise on Money, Vol. II: The Applied Theory of Money. London: Macmillan.

Keynes, J.M. 2007 [1936]. The General Theory of Employment, Interest, and Money. New York: Palgrave Macmillan.

Kregel, J. 2015. "Why Raising Rates May Speed the Recovery.” Levy Economics Institute Policy Note 2015/6.

Macrobond. various years. Macrobond, subscription service (accessed Sep 4, 2015).

Mitchell, W.F. 1998. "The Buffer Stock Employment Model and the NAIRU." Journal of Economic Issues 32(2): 547-56. 
Olson, M., and M.J. Bailey. 1981. "Positive Time Preference.” Journal of Political Economy 89(1): $1-25$.

Sakuma, K. 2015. "Why Declines in Long-term Interest Rates Are a Concern for the Economy?" Eyes of Institute for International Monetary Affairs No. 1, April. Available at: http://www.iima.or.jp/Docs/column/2015/0406 e.pdf

Samuelson, P.A. 1945. "The Effect of Interest Rate Increase on the Banking System." American Economic Review 35(1): 16-27.

von Mises, L. 1963. Human Action: A Treatise on Economics. New Haven: Yale University Press.

Wray, L.R. 1998. Understanding Modern Money: The Key to Full Employment and Price Stability. Northampton, MA: Edward Elgar. 